\title{
Beyond formal spaces
}

Reflections from the NSU Winter Symposium 'Feminism and Hospitality'

DOI: https://doi.org/10.30664/ar.91781

(c) Attribution 4.0 International (CC BY 4.0)

$\mathrm{T}$ his text offers some reflections that stem from my participation in the NSU Winter Symposium 'Feminism and Hospitality: Religious and critical perspectives in dialogue with a secular age', held in Turku, Finland, 5-7 March 2020. Drawing from my previous experiences both in my native country and in my country of residence, I first explain why this event represented a welcome novelty to me. I then highlight some of its major positive features. I do not offer a resume of the presentations or a collection of some of them. Rather, I focus on what, according to me, is the main strength of this kind of event. Based on the revision of my own presentation, I conclude by saying it may serve as a laboratory from whence to start the construction of bridges through which the dialogue between religion and secularism can really occur.

The DiAlogue between religious and secular spheres of society is among the most challenging of historical dialogues. Aware of the risk of any generalization, we can nevertheless easily perceive that many religiously informed people in my home country, Brazil, have difficulty in hearing arguments from outside their own religious perspectives and a tendency to appeal to their religious leaders as the source of political authority. The links between religious leaders and political constituted power increases the gap between religiosity and secularism.

The same kind of difficulty is perceived also in Italy, where I have been living since 2015, although there are many differences with Brazil, beginning with the variety of existing Christian denominations, which is huge in Brazil, while the vast majority of people in Italy are Roman Catholics. An appeal to Catholicism in Italy or to Evangelical denominations in Brazil (mainly neo-Pentecostalist ones) is strongly made by far-right parties and movements. But by contrast with what happens in Brazil, many people who prove to be sensitive to such an appeal are not particularly religious practitioners in Italy.

One key element to understanding this apparent paradox is that recently in Europe this specific appeal to Christian religiosity and traditionalism, linked to far-right parties, is often built against people of Islamic credo, specially migrants and refugees. ${ }^{1}$ This issue is virtually absent in Brazil,

1 This can be inferred from the findings of a comparative research published by the National Bureau of Economic Research at Harvard, published in June 2018 (Alesina et al. 2018). The misperceptions about the characteristics of immigrants are very high in all six countries where researchers conducted the survey (five European countries plus the US). These are largely correlated with the political orientation of the 
although the tendency of putting Christian religions against something else isn't. This 'something else' is usually a non-religion, often identified with secularism tout court. Every perspective that is associated with criticism of religiosity or, more specifically, of the influence of religious views in the political public arena is severely attacked by a large number of evangelical (and the more conservative wings of Catholic) practitioners.

Defenders of secularism also fall into the same closeness of dialogue, failing to hear the reasoning of people inspired by their religious beliefs (the classical Rawlsian background culture). The general feeling is that hearing those who think differently and engaging in a constructive dialogue has become virtually impossible.

In light of this, it is easy to understand why the NSU Winter Symposium, engaging religious and critical perspectives in dialogue, represented a gratifying surprise for me. This may sound strange to Nordic audiences, but it is a rare thing in Brazil. Coming neither from theological or religious studies, nor from a particular feminist approach in my own doctoral research, I nevertheless decided to send in a proposal, stimulated by an event that welcomed people coming from different fields of study and backgrounds as well as by the theme of the event, which was centred around the meanings of hospitality.

respondents. Right-wing respondents have the greatest misperceptions, and these more commonly appeal to Christian traditionalism, although, in actual fact, all groups of respondents overestimate the proportion of Muslim immigrants - in Italy, natives think it is five to six times higher than what it really is. This misperception is remarkably higher for countries such as Poland and Hungary (respectively 50 and 70 times higher than in reality). See Allievi 2018: 47.
From the first day, I was amazed by the excellent level of the presentations; many of them were about recently finished or ongoing researches. Maybe the time granted for each exposition - as in every academic seminar - allowed for little engagement between the presenter and the public following each presentation, but in this we were privileged, since we were granted an amazing organization that enabled us to spend a good amount of quality time in excellent conversations (and excellent food) outside of the official working hours.

The environment I found was open, engaging, and particularly provocative. Indeed, seeing people coming from different religions ${ }^{2}$ and - Christian - denominations in a friendly dialogue with others of no religious background was already enriching. Even more important was noting how both religious and critical perspectives can be strong aspects in the identity of the same persons. I am not saying this was something new to me - many of my religious friends place themselves in what we could loosely define the 'progressive' spectrum of religion, whatever this religion may be. But seeing, for instance, feminist women that are active in their respective religious communities, without abdicating from any of their beliefs, was somehow inspiring.

My interest in all of this is not merely intellectual but relates to a deep concern about how people manage to reconcile aspects normally considered irreconcilable in their own practices. Aware of my own male subjectivity, I understand the enormous importance of the role of women in this context, marked by a high degree of

2 The fact that there was no one of Islamic faith participating in the event represents perhaps its major limitation, especially considering its central theme. 
patriarchal practices and resistance to any challenge to their constituted morals.

The event lacked any form of 'heaviness' so typical of many academic symposia, and this 'informality' is central to understanding its importance. I would like to focus on this aspect, because it made me deepen my thinking about the role of academia in providing the tools for the construction of an open and inclusive society. And this happened through the revaluation of my own presentation, which was purposely informal and discussion-oriented.

Inspired by a text of a Brazilian preacher, Reverend d'Araújo Filho, about the differences between the morality of religion and the ethics proposed by Jesus (d'Araújo Filho 2005), I had proposed a reading of a passage of the book of Luke (10:38-42) in which tells of an occasion when Jesus was hosted by a woman named Martha. Her sister Mary does not help her in 'the preparations of what needs to be made', preferring to sit and listen to Jesus. Martha's complaints to Jesus, however, are not accepted, as Jesus replies that Mary had made the best choice.

As a host, Martha acted perfectly morally, doing what a woman of her status in that society would be asked to do. A 'heavy' academic discussion on this passage could start exactly around the attribution of the qualifying adverb 'morally' to Martha's attitude, a word which is, by the way, absent from the biblical text. We could identify Mary's choice an ethical one, while calling Martha's a moral choice. Conversely, we could say Martha's choice was according to the ethics of a group, while Mary's one was moral, because identified with an individual path of her own. This discussion would concentrate on the meanings of the Latin translation of two Greek words: $\tilde{\eta} \theta$ oc (èthos) and عُ $\theta$ oc (ethos), and on our common uses of the words 'morality' and 'ethics'. This was part of my original presentation, but I came to realize that if we follow this kind of exposition, we are almost certainly addressing an academic or, in more general terms, a cultivated public. Certainly, this public can be a religious one, but it will rarely be the general public to which religious leaders address themselves. The challenge lies in the fact that, in a democracy, this general public is part of the mechanism that builds up the government and the institutions, both through the ballots and through the different ways of applying pressure to and influencing governmental policies and decisions.

We could follow another kind of analysis: moving the focus from the meaning to the nonconformist act of Mary. Indeed, Mary's act becomes capable of radically contesting one's groups' own perceptions of what it means to be moral, and opens up the possibility of not being afraid of standing against a certain kind of morality, one that connects to any form of inherited habits, perceptions and even beliefs. This focus-change can appear to be meaningless to the academic public, but it is not to the general religious public outside universities or study circles. Moreover, this perspective can identify with others that have historically been radically critical of religiosity and of religion-based traditions, such as those of feminist studies and feminist practice. This is because they converge in proposing a modified public praxis, one that follows a rich culture of individuality, capable of deserting the paths of conformism and mimesis of dominant models.

An academic event is just a small step in the construction of this kind of identification. But if it is an event such as this NSU Winter Symposium, it helps to bridge the gap between formal spaces of religion and those of high education. In doing so, it may become an important laboratory from where to start the construction of bridges 
through which the challenging dialogue between religion and secularism can really occur.

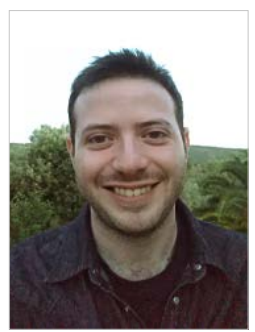

Israel Barroso is a $\mathrm{PhD}$ candidate in Political Philosophy, as part of the programme 'Human Rights and Global Politics: Legal, Economic and Philosophical Challenges' at Sant'Anna School of Advanced Studies in Pisa, Italy. He holds a BA in History from the Federal University of Santa Catarina, Brazil, and a MA in International Relations (cum laude) from the University of Bologna, Italy. In his doctoral research, he investigates the historical transformations of the concepts of fraternity/solidarity as political principles and the potential for them to foster cooperation among international actors, especially when addressing issues of common concern, such as climate change.

\section{References}

Alesina, Alberto, Armando Miano, and Stefanie Stantcheva. 2018. 'Immigration and redistribution', NBER Working Paper Series (Cambridge, MA: National Bureau of Economic Research at Harvard), <https://www. nber.org/papers/w24733.pdf $>$ (accessed 30.6.2020).

Allievi, Stefano. 2018. 5 cose che tutti dovremmo sapere sullimmigrazione (e una da fare) (Bari and Rome: Laterza).

d’Araújo Filho, Caio Fábio. 2005. 'Entendendo a ética da vida e a ética do "telhadão", Caio Fábio [website], 31.12.2005, <https://caiofabio.net/entendendo-a-etica-da-vida-e-a-etica-do-telhadao $>$ (accessed 22.4.2020). 